Sultan Qaboos University Journal of Arts \& Social Sciences

\title{
Translation and EFL in Oman
}

\begin{tabular}{c}
\hline Musallam Al-Ma'ani \\
\hline Assistant Professor \\
$\begin{array}{c}\text { Sultan Qaboos University, Oman } \\
\text { musallam@squ.edu.om }\end{array}$
\end{tabular}

$\frac{\text { Al Ghalia Al-Kindi }}{\text { Ministry of Education, Oman }}$

Al Ghalia Al-Kindi

Ministry of Education, Oman 


\title{
Translation and EFL in Oman
}

\author{
Musallam Al-Ma'ani and Al Ghalia Al-Kindi
}

\section{Abstract:}

The history of the didactics of translation indicates that it has been effectively used in the teaching of foreign languages. In the case of English as a Foreign Language (EFL), translation can have a sufficiently facilitating role in its teaching and learning. Particularly for the teaching of EFL in Oman, where English is taught at all stages of the educational system, translation from and into Arabic and English may improve the mastery of English. But there is disagreement among EFL teachers on the use of translation in their classes. This paper explores the views of EFL teachers in Oman with regard to the feasibility and usefulness of translation in EFL teaching. Findings suggest that EFL teachers in Oman are almost split on this vital issue.

Keywords: Translation, Foreign Language, Learning, EFL Teachers

\section{الزرجمة واللغة الإنجليزية كلغة اجنبية في سلطنة عمان}

\author{
مسله المعني والغالية الكندي
}

\footnotetext{
الملخص:

يوضح تاريخ تدريس الترجمة أن الترجمة استخدمت بشكل فاعل في تدريس اللغات الأجنبية، ففيما يتعلق بتدريس اللغة الإنجليزية

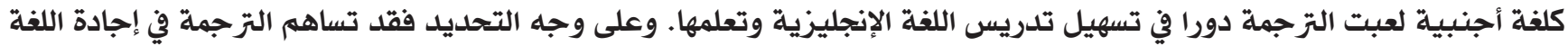

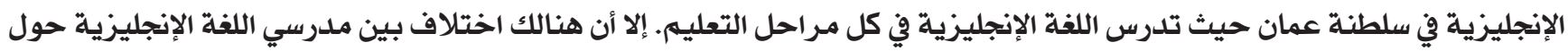

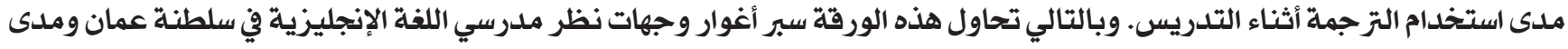
جدوى التزجمة وفائدتها في تدريس اللغة الإنجليزية. وتشير نتائج البحث إلى عدم توافق آراء ملدرسي اللغة الإنجليزية بسلطنة التئة عمان في

هذه المسألة.
} 


\section{1- Introduction}

The use of translation in teaching and learning a foreign language is not a new activity. Munday (2008) indicates that translation has often been used in learning new languages especially for beginners until they show considerable competence in the foreign language. Vermes (2010) points out that bilingual education in ancient Rome was based on employing translation as a tool for analyzing and interpreting the contents of books mostly in the form of word-forword translation.

In the 18th century, the grammar-translation method (GTM) was introduced for the purposes of teaching foreign languages. Richards and Rodgers (1986, p. 2) explain that within this method, the teaching procedure was based on text books consisting of "statements of abstract grammar rules, lists of vocabulary, and sentences for translation". According to Vermes (2010), the need for GTM revolved around developing earlier language teaching practices with the aim of teaching modern languages to as many students as possible. Larsen-Freeman (1986) agrees with Vermes (2010) by saying that GTM, or the classical method as it was called before, not only aimed at enabling learners to be familiar with the grammar of the foreign language, but also with their own mother tongue (first) language. Richards and Rodgers (1986) further argue that this method focuses on providing learners with the necessary grammatical rules and paradigms, but also simple sentences to translate in the form of a mechanical translation with the aim of getting learners to apply the grammar rules through suitable translation tasks. This way, it can contribute to creating an effective foreign language teaching environment.

However, despite this checkered history, the use of translation in foreign language teaching has been considered by some educationalists, like Vermes (2010: 83), as an "outlaw" practice especially after the introduction of approaches such as the natural, the audio-lingual, or the communicative, among others, particularly during the second half of the 20th century. Failing to prove its functionality, GTM was rejected on the basis of several statements of generalization such as "all translation is bad" (Taylor, 1972: 182).

The teaching methods shifted to communicative and natural approaches; thus marginalizing the status of translation as a teaching and learning tool. Atkinson (1987) notes that the use of translation in classrooms has been neglected or avoided for a long time not only in teacher training, but also in the arguments or research on methodology as a result of associating it with GTM. All this notwithstanding, the role of translation as a classroom resource is essential in developing foreign language fluency, and for this reason it should be reevaluated and considered for its potential merits.

Today, the use of translation in EFL classrooms has become synonymous with expressions such as the use of the mother tongue language, the use of L1 (language one or first language), code-switching or code-mixing, bilingualism, among others. Although they may seem different, they all point to the same notion of the alternate use of L1 and L2 for the purposes assisting learners acquire the foreign language.

Since translation is optimally seen as a process that "consists of transferring the meaning of the source language into the receptor language" (Larson, 1984: 3 ), its role in language teaching is important as it "develops three qualities essential to all language learning: accuracy, clarity and flexibility. It trains the learner to search (flexibility) for the most appropriate words (accuracy) to covey what is meant (clarity)" (Duff, 1994: 160). However, the use of translation by EFL teachers in classrooms is unique in itself and different from the traditional perception of translation. Within an EFL context, the switching in the use of two languages is not governed by the traditional norms of translation where translators are required to analyze the different facets of the text to "ensure full comprehension and correct interpretation of the text or explain its linguistic and textual structures and their relation $\neg$ ship with the system and norms of the source language (SL)" (Nord, 2005, p. 1). Given the contested position of translation for EFL purposes, the aim of this paper is to engage the views of EFL teachers in the Sultanate of Oman as to where translation stands or should stand vis-à-vis EFL teaching and learning.

\section{2-Translation and EFL}

Many researchers believe that translation is very useful in EFL classrooms. Atkinson (1987) advocates that translation boosts foreign language learning. Similarly, Pan and Pan (2012) present some advantages or "positive effect" as they term them, of using translation in EFL classrooms. They argue that translation enhances learners' awareness about similar and different linguistic features of both languages, source language (SL) and target language (TL). This awareness augments the foreign language learning and prevents learners from producing utterances influenced by their native tongue. 
Miles (2004) supports the bilingual approach that enables learners to achieve an adequate level of comprehension, particularly when explaining complex grammatical rules. Al-Hinai (2006) encourages the use of L1 in EFL classrooms for humanistic and psychological reasons concerning the learners, such as reducing the level of unease or tension as well creating a more comforting and peaceful learning atmosphere. Here, the translation method also functions as a communication tool mediating between teachers and learners. It enables the two parties to communicate when the use of only one medium fails or cannot be used.

Vermes (2010) also considers the usefulness of translation for both spoken and oral skills. He argues that translation promotes the fluency of spoken language(s) where teachers get learners to translate orally few SL sentences into the TL. By doing so, oral translation exposes learners to a variety of TL patterns produced by different learners. Other educationalists also look at translation from a psychological aspect especially when it comes to relieving learners' anxiety in EFL classrooms. Stibbard (1998) points out that translation exercises play a major role in reducing the level of learners' anxiety and stress, particularly during the earlier stages of language learning. Creating a stress-free learning environment may positively contribute to creating effective foreign language teaching.

However, it can be generally said that translation is used in EFL classrooms for various reasons. The use of translation in an EFL classroom is perhaps different from other forms of translation where there is a source text and the translators have to carry the message to other languages. Taylor (1972) argues that foreign language teachers use translation in order to assist learning by making clear what is unclear to their learners. He emphasizes that the use of translation is not the focal point in itself; rather it is how translation is used in EFL classrooms. He suggests three major principles, as he terms them, if the translation approach is to be followed. These principles are linked to who does the translation, the level of the translation and what to translate.

The first principle suggests that translation should be done by EFL teachers not the learner(s). This may take the form of teachers spelling out correct information. However, if learners were asked to translate, they would rely on guesswork, thus making the learning process confusing. At a higher level, the second principle focuses on the level at which translation is done: word, clause or sentence level. Taylor (1972) argues that good translators or teachers, as in this case, should only translate at a level higher than the word level. In other words, it should be carried out at the levels of the clause or sentence. By doing so, a word-for-word translation is avoided, enabling the learners, especially the beginners, to comprehend and function at higher levels. The third and last principle deals with a very common yet vital questionwhich concerns many EFL teachers: when to use translation? Taylor (1972) answers this question by saying that translation should only be used when the communication between the teacher and learners is at stake and about to break down. In other words, translation should be used as a mediatory means to overcome the barrier of understanding the foreign language rather than focusing on translation for the sake of teaching it.

Several uses of translation in monolingual classrooms are stated in Atkinson (1987). Here are some examples of the uses of translation associated with teaching. Teachers can elicit language from learners by asking them directly "How do you say $X$ in English?" ( $p$. 243). Such a simple question not only may stimulate learners' knowledge but also may save both time and effort consumed if other methods such as visual cards or miming are used. Translation can play a great role in checking learners' level of comprehension with regard to conceptual structures. For example, the use of first language to instruct learners to produce a certain sentence structure in the TL may encourage learners to acquire the skill of distinguishing between the structural, semantic and pragmatic equivalence. Giving instructions to learners of early levels of TL through the use of translation may sound helpful. It could be done the other way around, where the teacher gives the instruction in the TL and gets learners to repeat it using the mother tongue language. Discussing the classroom methodology with learners of early levels (e.g. beginners), especially at the very beginning of the teaching course, is highly recommended either by using a combination of the two languages, SL and $\mathrm{TL}$, or only by learners' mother tongue language. Such a measure may be beneficial to both the teaching and learning processes because it provides teachers and learners with an opportunity to exchange views and opinions concerning the course. In other words, Atkinson (1993) concludes that the use of L1 can be regarded as a useful and effective tool only when used appropriately at proper times.

Pan and Pan (2010) agree with the abovementioned 
translation uses of Atkinson (1987) and also advocate wise and judicious use of the mother tongue language through avoiding at all times its unnecessary use. Listing other uses of translation, different researchers argue that L1 is principally used for different pedagogical reasons including ways to: "provide scaffolding for tasks (Anton \& Dicamilla, 1998), to promote the transition from L1 to TL use (Shamash, 1990), to improve negotiations (Swain \& Lapkin, 2000), and to enhance TL comprehension (Turnbull, 2001)" ( Pan \& Pan, 2010, p. 88).

Pan and Pan (2010) list four factors of guidelines that teachers need to consider when using L1: efficiency, learning, naturalness and external relevance; explained as follows. First, efficiency means that teachers may use L1 to achieve maximum efficiency with minimum time and efforts, especially when dealing with abstract and difficult vocabulary. Secondly, learning means that teachers may use L1 to facilitate the learning process through giving sufficient explanations of complex issues. Thirdly, naturalness means that teachers may use L1 to create a natural and stress-free classroom environment with the aim of building tied bonds with the learners. Fourthly, the external relevance guideline means that teachers may use L1 establish an external relevance between the use of L1 and L2 inside the classroom and outside the classroom as a life skill. It is more about dealing with languages beyond the classroom context.

However, Yavuz (2012) argues that the use of L1 has been a subject of debate throughout the history of English language teaching. Whereas there are those who stand firmly with the use of $L 1$, there are others who discourage the use of L1 in EFL classrooms. Opponents of the use of translation in EFL classrooms argue that the overuse or misuse of L1 in EFL classrooms, originally designed to practice $L 2$, affects and reduces learners' exposure to the foreign language. Al-Shidhani (2009) points out that some teachers may avoid the translation method thinking that the use of L1 contradicts with such communicative methods and that some teachers regard the translation method as a barrier that blocks language learning, regardless of its potential usefulness. Newson (1998) points out that translation does not contribute in fulfilling the aims of foreign language teaching neither in terms of the spoken language fluency, the target selection of structures and lexical items, nor the communicative strategies. Malmkjær (1998) also lists several points signaling her objection to the use of translation in EFL classrooms. She believes that the use of translation in EFL classrooms is not a natural process and may mislead learners, who may wrongly think that languages have one-to-one correspondents, and that translation interferes with the learning and thinking process. When teachers refer to translation, learners in return opt for it as well to establish active participation, which ultimately deprives them from using the foreign language. Carless (2008) voices a similar view by arguing that the use of translation may involve a risk of discouraging the learners from practicing the foreign language. Kharma and Hajjaj (1989) also think that since L1 is available, translation demotivates learners from being actively involved in the foreign language learning process.

\section{3-Translation and EFL in Oman}

English in modern Oman is widely used in various sectors. Moody (2012, p. 17) argues that "Arabic is the dominant language throughout the Gulf region [including Oman], used for both internal and external communication and ... English has traditionally been seen here as a means for international communication further afield". Al-Busaidi (1995) concludes that English is not only used in the business sector, but also in other sectors like education and mass media. Road and business signs in Oman are all written in both languages: Arabic and English. Kapiszewski (2006:4) estimates that $19.9 \%$ of expatriates live in Oman use English.

This is why English is seen by Al-Bulushi and Al-Issa (2012, p. 270) as "the only official foreign language in the Sultanate of Oman" and receives considerable political, economic and legislative attention and support from the government". Mahmoud and AlMahrooqi (2012: 9) report on the language landscape in Oman where English is "gaining ever more prominence as countries rush to embrace modernity and economic development and become part of the modern world".

The implication of this widespread use of English is that it is taught officially not only in private schools, but also in public schools where, according to Al-Bulushi and Al-Issa (2012), students start learning English from Grade 1 in the 12 grade general secondary diploma system in Oman; thus creating an atmosphere of a foreign language educational process in the country. However, Omani students face challenges in learning English. The first and foremost challenge is that English cannot replace the Arabic language in almost all spheres of life. A large portion of Omani families do not speak English and even if they do, they do not use 
it in their daily communication and interaction with each other in society at large. In other words, English is not used as a communication medium outside educational establishments and perhaps outside the circles of young Omanis, who tend to use a mix of Arabic and English in their interaction. This is why the status of English as a foreign language in the Gulf region, in general, and despite huge investments in its teaching and despite the colonial and current strong links with the United States and Britain, still points to disappointing results as to its mastery and use.

\subsection{Methodology}

To ascertain the views of those at the front line, so to speak, this paper reports the views of EFL teachers on the use and effectiveness of translation in their EFL classes. To this end, a questionnaire was given to English language teachers from different schools in the Muscat Governorate, Sultanate of Oman. Teachers were invited to respond to the questionnaire on a voluntary basis and could submit their feedback either electronically or in person to the authors. The teachers were asked to share their opinions on the use of translation as a helping tool in the teaching of English to Omani students, and to provide suggestions on the effective use of translation in EFL classrooms. The questionnaire, given in Appendix 1 , is divided into two parts: Part 1 (Questions 1-13) focuses on soliciting the views of the teachers on the use of translation in EFL classrooms in Oman, and part 2 (Questions 14-16) focuses on general questions (whether the teachers employ translation and the reasons for doing so). This part also allows the teachers to provide suggestions on how to improve the standards of English among Omani students.

\subsection{Results and Discussion}

In total, 45 teachers completed the questionnaires. Figure 1 summarizes the responses of the teachers to the questions in the questionnaire, where $Q 1=$ question 1 , etc.

For part 1 of the questionnaire (questions 1 to 13 ), the analysis of the teachers' responses shows:

- Question 1: $55 \%$ of the teachers support the use of translation as they see it contradicting with the objectives of the teaching of English.

- Question 2: 30\% of the participants believe that teachers should minimize the use of translation with learners of higher grades, i.e., grades 3 or 4 , whereas $40 \%$ believe that translation can be used in higher grades and $30 \%$ were unsure.
- Question 3: This question seems to have been slightly controversial. Participating teachers seemed to be split into almost 50/50 (44.5\% agreed and the same were unsure). Only $11 \%$ disagreed. These figures indicate that serious research is urgently needed to investigate the impact of the use of Arabic (positive or negative) on the teaching and learning of English in Oman.

- Question 4: 69\% of the teachers disagreed with the statement, pointing out that only inexperienced teachers use translation in English classrooms, although experience does not play a role in deciding whether the native language should be used or otherwise in a foreign language classroom.

- Question 5: Only $41 \%$ of the teachers thought that there is a need for training in the use of translation in classroom. $30.5 \%$ were unsure and $28 \%$ disagreed with the need for training.

- Question 6: $48 \%$ of the teachers were unsure about the usefulness of translation as a teaching tool in EFL classrooms. $25 \%$ agreed with the statement, while $28 \%$ disagreed. This may suggest that perhaps EFL teachers in Oman are not well versed on the merits or otherwise of the use of translation in the teaching of English.

- Question 7: $44.5 \%$ of the teachers agreed with the idea that English teachers should be allowed to use translation in their EFL classroom, but $30.5 \%$ of teachers disagreed. This may indicate that almost half of the teachers who responded to the questionnaire faced situations whereby they had to use translation to facilitate EFL learning and teaching.

- Question 8: 53\% of the teachers agreed with the statement that using translation with young learners is necessary, but $30 \%$ of them disagreed with it.

- Question 9: 64\% of the teachers disagreed with the notion that teachers use Arabic because they feel that this is what their students want. This may indicate the teachers' awareness of the use of translation and L1 depends on the needs of the objectives and material taught, not the students.

- Question 10: $41.5 \%$ of the teachers were unsure about the statement because of the view that "incompetent" teachers use translation in EFL classes. This indicates that the language competence in some cases might play a major role in whether to use translation or not in EFL classes.

- Question 11: 39\% of the teachers disagreed with the notion saying that teachers tend to use translation less when the lesson is observed by the head teacher, the supervisor, the senior English teachers (SET), or even 


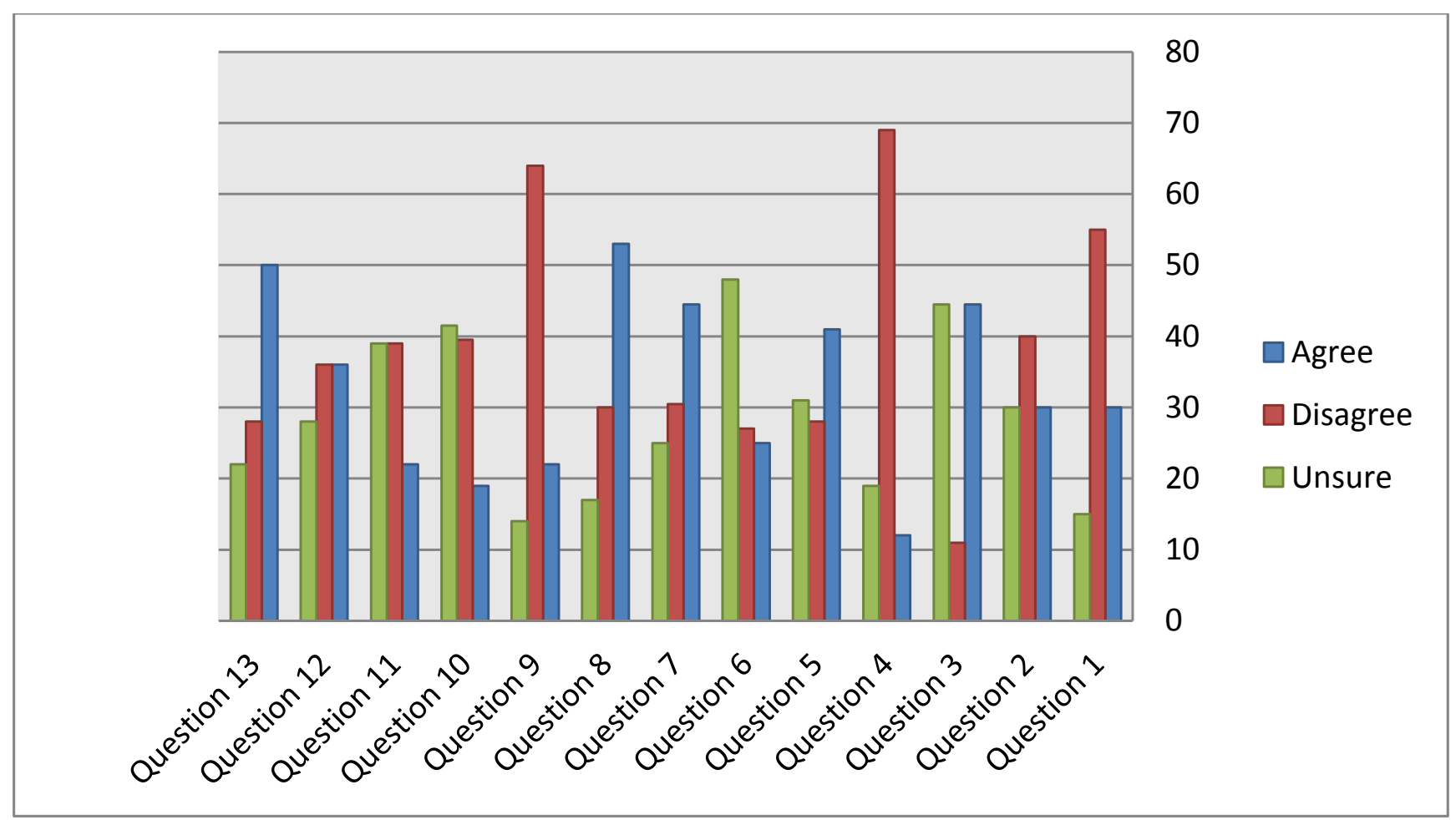

by a colleague. $39 \%$ were unsure and $22 \%$ agreed with the statement. This may indicate that in most cases teachers decide to use translation or not in their EFL classes without being fully aware of the ramifications of their decision, and even worse, they might not be convinced of the merits of their decision. They simply follow given instructions as long as the administration is happy. Further, teachers may even be confused given the usually "unstable" opinions of supervisors and specialists when it comes to the use of translation in EFL classes.

- Question 12: Equal percentages of 36\% showed the different opinions among teachers about the usefulness of using Arabic in creating a comfortable and stress-free learning environment. Only $28 \%$ were not sure. It is possible that teachers simply do not pay enough attention to this factor in teaching and learning.

- Question 13: 50\% of the teachers agreed with the notion that English language teachers should only use English. 28\% disagreed, while $22 \%$ were unsure. This may indicate that teachers are a bit hesitant about their views regarding the use of translation because for question $7,44.5 \%$ of the teachers agreed with the use of translation.

For part 2 of the questionnaire (questions 14 to 16), a synthesis of the responses provided by the participating EFL teachers is summarized as follows:
On the reasons they use translation in their classes, around $86 \%$ of the teachers indicated that they use translation in their classes only on certain occasions, particularly when they find that the majority of the class does not comprehend a given content such as difficult or abstract vocabulary items, games, stories, classroom instructions, rhymes, etc. These teachers also indicated that they usually follow the instructions in the teacher's book where, in some cases, they allow the use of translation to maximize learners' level of understanding and participation. They also stated that they use translation to introduce information and knowledge outside the textbook, for example good manners, hobbies, etc. On the other hand, the remaining $14 \%$ of the teachers who responded to the questionnaire opposed the use of translation in English classes outright. These teachers stated that they do not use translation in their classes because they think that the message in a foreign language learning context can be conveyed through the use of body language, dictionaries, visual aids and materials, etc. They also think that the learners can, to a certain extent, understand and learn the foreign language without the need to resort to translation as an intermediary medium. They further added that students would learn the foreign language "better and more" if they are exposed to it, adding that it would be unfair not to expose learners to English 
during lessons because it may well be the only chance for students to be exposed to it.

On what influences their use of translation in their EFL classes, most of the teachers, who responded to the questionnaire, said that they are mainly influenced by the learners' level of achievement, their background knowledge about the content, especially in introductory lessons at the beginning of each unit. The teachers further indicated that as long as translation is used in EFL classes, both teachers and learners need to maximize its benefits as a supporting tool in teaching and learning English, particularly that translation may well save time and energy for both teachers and students alike. The teachers also indicated that translation could be a good testing tool in EFL classes. For these teachers, the use of translation in an EFL context creates a flexible learning environment and enhances learners' motivation to learn English.

\section{4- Conclusion}

Translation has a role to play in EFL. As Kramsch (2014) suggests translation is the site for exploring "differences in meaning, mentality, and worldview" (p. 252), and further adds:

If we extend the notion of translation to a pedagogic principle that leads to translingual and transcultural competence, then "translation" would become central to the multilingual mindset we teachers need to develop. It would mean systematically designing exercises in translation, transcription, transposition - exercises that would systematically practice the transfer of meaning across linguistic codes, discourse frames, media and modalities. (op. cit., p. 252)

As such the use of translation in the teaching and learning of EFL has a role, but there is currently no real agreement as to what aspects of and how this role can be integrated into EFL. The views of the EFL teachers in Oman discussed in this paper indicate that translation is seen a double-edged sword -it has to be used carefully and teachers need to be aware of its positive and negative aspects and dimensions. In the case of EFL in Oman, the survey of the opinions of 45 EFL teachers in the Governorate of Muscat, shows that although the use of translation is supported by the majority of EFL teachers, the main conclusion is that its use in an EFL environment should be the last resort, not the first or the easy way out. Teachers can employ other non-verbal communicative strategies that may help students' understanding and comprehension.
Field work-based research is needed to make any generalizations that may become recommendations for the incorporation of translation in the teaching and learning of EFL in Oman, in particular, and perhaps the wider Arab World.

\section{References}

Al-Busaidi, K. (1995). English in the Labour Market in Multilingual Oman with Special Reference to Omani Employees. Unpublished Ph.D Thesis. Exeter: University of Exeter.

Al-Bulushi, A. \& Al-Issa, A. (2012). Investigating Omani Learners' Out of-Class English language learning Strategies. In Mahmoud, A. \& Al-Mahrooqi, R. (Eds.), Issues in Teaching and learning English as a Foreign Language in the Arab World (pp. 271-294). Muscat: Sultan Qaboos University.

Kramsch, C. (2104). The Challenge of Globalization for the Teaching of Foreign Languages and Cultures. Electronic Journal of Foreign Language Teaching, 11 (2), 249-254.

Mahmoud, A. \& Al-Mahrooqi, R. (2012). Introduction, In Mahmoud, A. \& Al-Mahrooqi, R. (Eds.), Issues in Teaching and learning English as a Foreign Language in the Arab World (pp. 11-16). Muscat: Sultan Qaboos University.

Moody, J. (2012). A Critique of the Concept of EFL in Arabian Gulf Countries, In Mahmoud, A, \& AlMahrooqi, R. (Eds.), Issues in Teaching and learning English as a Foreign Language in the Arab World (pp. 17-46). Muscat: Sultan Qaboos University.

Al-Hinai, M. (2006). The use of the I1 in the Elementary English Language Classroom. Classroom Research in English Language Teaching in Oman, 8-14.

Al-Shidhani, A. (2009). Teachers' Beliefs about Using Arabic in the English Classroom. Classroom Research in English Language Teaching in Oman, 184-191.

Atkinson, D. (1987). The mother tongue in the classroom: a neglected resource?. ELT Journal, 41(4), 241-247.

Duff, A. (1994). Translation. Oxford: Oxford University Press. 
Kapiszewski, A. (2006). Arab versus Asian Migrant Workers in the GCC countries. Beirut: United Nations Department of Economic and Social Affairs.

Kharma, N. \& Hajjaj, A. (1989). Use of the mother tongue in the ESL classroom. IRAL, 27, 223-234.

Larsen-Freeman, D. (1986). Techniques and Principles in Language Teaching. New York, NY: Oxford University Press.

Malmkjær, K. (1998). Introduction: Translation and Language Teaching. In K. Malmkjaer, (Ed.), Translation \& Language Teaching: Language Teaching \& Translation, (pp. 1-11). Manchester, UK: St. Jerome Publishing.

Miles, R. (2004). Evaluating L1 use in English Language Classroom. M.A Thesis. United Kingdom: Brimingham University. Retrieved from http://www.bhamlive3. bham.ac.uk/Documents/collegeartslaw/cels/essays/ matefltesldissertations/Milesdiss.pdf

Munday, J. (2008). Introducing Translation Studies. (2ND edn.). New York, NY:

Routledge.

Newson, D. (1998). Translation and Foreign Language Teaching. In K. Malmkjaer, (Ed.), Translation \& Language Teaching: Language Teaching \& Translation, (pp. 63-68). Manchester, UK: St. Jerome Publishing..

Nord, C. (2005) Text Analysis in Translation. Theory, Methodology, and Didactic Application of a Model for Translation-oriented Text Analysis. Amsterdam, NewYork: Rodopi.

Pan, Y. \& Pan, Y. (2012). The Use of Translation in the EFL Classroom. Philippine ESL Journal, V9, 4-23.

Taylor, C. (1972). Why Throw out Translation?. In D. Byrne (Ed.). (1980) (4th edn.). English Teaching Perspective (pp. 182-184). Singapore: Longman.

Richards, J. C. \& Rodgers, T. S. (1986). Approaches and Methods in Language Teaching: A description and analysis (6th edn). New York: Cambridge University Press.

Stibbard, R. (1998). The Principled Use of Oral Translation in Foreign Language Teaching. In K.
Malmkjaer, (Ed.), Translation \& Language Teaching: Language Teaching \& Translation, (pp. 69-76). Manchester, UK: St. Jerome Publishing.

Vermes, A. (2010). Translation in Foreign Language Teaching: A Brief Overview of Pros and Cons. Eger Journal of English Studies X, 83-93.

Yavuz, F. (2012). The Attitudes of English Teachers about the Use of L1 in the Teaching of L2. ProcediaSocial and Behavioral Sciences, 46, 4339-4344. doi: 10.1015/j.sbspro.2012.06.251. 
Appendix (1) Data Collection Instrument: Questionnaire

Part 1: Teachers' Perspectives on the Use of Translation

\begin{tabular}{|c|c|c|c|c|}
\hline & Statements & Agree & Unsure & Disagree \\
\hline 1 & $\begin{array}{l}\text { Can English teachers speak Arabic as much as possible in EFL class- } \\
\text { rooms? }\end{array}$ & & & \\
\hline 2 & $\begin{array}{l}\text { Should teachers keep the use of (Arabic) translation to its minimum } \\
\text { with learners of higher grades (e.g. G4)? }\end{array}$ & & & \\
\hline 3 & $\begin{array}{l}\text { Does the use of translation have a negative impact on learning } \\
\text { English? }\end{array}$ & & & \\
\hline 4 & $\begin{array}{l}\text { Can inexperienced teachers sonly use translation in English class- } \\
\text { rooms? }\end{array}$ & & & \\
\hline 5 & $\begin{array}{l}\text { Do teachers need more training on the use of translation in English } \\
\text { classrooms? }\end{array}$ & & & \\
\hline 6 & Is the use of translation in EFL classrooms a useful teaching tool? & & & \\
\hline 7 & Should teachers be allowed to use translation in EFL classrooms? & & & \\
\hline 8 & $\begin{array}{l}\text { Is the use of translation in EFL classrooms necessary with younger } \\
\text { learners? }\end{array}$ & & & \\
\hline 9 & $\begin{array}{l}\text { Do EFL teachers use Arabic because they feel that this is what pu- } \\
\text { pils want? }\end{array}$ & & & \\
\hline 10 & $\begin{array}{l}\text { Do EFL teachers use Arabic/translation if they feel they are incom- } \\
\text { petent in English? }\end{array}$ & & & \\
\hline 11 & $\begin{array}{l}\text { Do EFL teachers tend to use translation less when the lesson is } \\
\text { observed (e.g. by Head Teachers, SETs or RSs)? }\end{array}$ & & & \\
\hline 12 & $\begin{array}{l}\text { Does the use of translation create a comfortable and stress-free } \\
\text { learning environment for EFL learners? }\end{array}$ & & & \\
\hline 13 & Should EFL teachers use English only in EFL classes? & & & \\
\hline
\end{tabular}

\section{Part 2: Open-answer questions}

14. Do you use (Arabic) translation in your classes? Why?

15. What influences your decision to use or not (Arabic) translation in your EFL classes?

16. Please provide any comments or suggestions on the effective use or otherwise of translation in EFL classrooms. 